\title{
Breast Intracanalicular Fibroadenoma
}

National Cancer Institute

\section{Source}

National Cancer Institute. Breast Intracanalicular Fibroadenoma. NCI Thesaurus. Code C4271.

A morphologic variant of breast fibroadenoma without clinical significance. It is characterized by distortion and compression of the ducts by proliferating stromal cells. 